\title{
Riske Maruz Değer ve Borsa İstanbul'da İşlem Gören Bazı Enerji Sektörü Hisse Senetleri Üzerine Bir Uygulama
}

\author{
Fatih ÇEMREK*1๑, Tuğba BíTiRGEN2 \\ ${ }^{1}$ Eskişehir Osmangazi Üniversitesi, Fen-Edebiyat Fakültesi, İstatistik Bölümü, 26040, Eskişehir, Türkiye \\ ${ }^{2}$ Kütahya Valiliği Altıntaş Kaymakamlığı, 43800, Kütahya, Türkiye
}

(Alınış / Received: 01.01.2021, Kabul / Accepted: 14.04.2021, Online Yayınlanma / Published Online: 15.08.2021)

Anahtar Kelimeler Riske Maruz Değer, Volatilite Tahmin Yöntemleri, BIST 50, BIST 100
Özet: Riske Maruz Değer (RMD), yatırım yapılan portföylerin elde tutma süresi adı verilen süre sonunda beklenilen olası kaybını belirlemek amacıyla yapılan hesaplamalardır. RMD ayrıca, olası portföy kayıplarının basit istatistiksel bir ölçüsü olarak tanımlanmaktadır. Volatilite, belirli bir zaman aralığı içerisinde finansal getirilerde yașanan oynaklığ ifade etmektedir ve Riske Maruz Değer hesaplamalarında büyük önem arz etmektedir. Bu çalışmada, BIST 50 ve BIST 100 şirketleri içerisinde bulunan ve enerji sektöründe yer alan üç şirket için 20082018/05 dönemi için aylık kapanış fiyatları incelenmiş ve volatilite tahmin yöntemlerinden en uygun model bulunması amaçlanmıștır. Analizde karșılaștırılan dört farklı model içinden en uygun volatilite modeli GARCH(1,1) olarak elde edilmiştir. Sonrasında ise Riske Maruz Değer yaklaşımlarından Tarihi Simülasyon yöntemi ile Riske Maruz Değer elde edilmiștir.

\section{An Application on Value at Risk and Some Energy Sector Stocks Traded on Borsa Istanbul}

\section{Keywords}

Value at Risk, ISE 50,

ISE 100
Abstract: Value at Risk (VAR) is calculations on the purpose of determining the expected loss of the invested portfolios at the end of the period called retention period. VaR is also defined as a simple statistical measure of possible portfolio losses. Volatility refers to the changefulness experienced in financial income within a certain time interval, and it has great significance in the calculation of theValue at Risk (VaR). In this study, monthly closing prices for the period of 2008-2018 / 05 were examined for three companies in the energy sector within BIST 50 and BIST 100 companies, and it was aimed to find the most suitable model among the volatility estimation methods. In the analysis, the most suitable volatility model is obtained as GARCH $(1,1)$ among the four different models compared. Subsequently, Value at Risk is obtained by using Historical Simulation method.

\section{Giriş}

Günümüzde, teknolojinin gelişmesi günlük yaşantımız üzerinde etkili olan en önemli faktörlerden birisidir. Dünyada ekonomilerin liberal olmaları nedeniyle ulusal ve/ya çok uluslu şirketlerin günün her anında işlem yapabildiği piyasaların varlığı ve işlem gören menkul kıymetlerin çeşitlilik göstermesi gibi etmenler nedeniyle dünya ekonomisi tek pazar olarak görülmesini sağlamaktadır. Bu hızlı değişime uyum sağlamak, ülkeler ve küçük ya da büyük olmasına bakılmadan tüm yatırımcılar açısından önemli birgerekliliktir [1]. Günümüzde enerji, üzerinde durulan ve araştırılan en önemli konulardan birisidir.
Türkiye, OECD ülkeleri arasında, son 10 yıl içerisinde enerji talebinde en hızlı büyüme sağlayan ülkelerden birisidir. Türkiye'de enerji kaynaklarının yetersiz olması nedeniyle, petrol ve doğal gazı dışarıdan temin etmekte ve bu enerjiler için için ithalat bağımlılığı yüksektir.

2023 yılına kadar Türkiye'nin enerji sektörüne yatırım ihtiyacının 120 ile 130 milyar ABD Doları'nı aşacağı beklenmektedir [2]. Bu durumlar dikkatle incelenirse, enerji sektörü Türkiye açısından önemli olduğu anlaşılmaktadır.

2023 yılına kadar Türkiye'nin enerji sektörüne yatırım ihtiyacının 120 ile 130 milyar ABD Doları'nı 
aşacağ beklenmektedir [2]. Bu durumlar dikkatle incelenirse, enerji sektörü Türkiye açısından önemli olduğu anlaşılmaktadır.

Ölçüm riski kavramı, yatırımcılar ve portföy yöneticileri için önemlidir. Finans alan yazını son yıllarda bu kavram üzerine yoğunlașmıștır. Bundan dolayı, Riske Maruz Değer (RMD) analizi, finansal risk yönetimi için önemli hale gelmiştir. RMD analizi, elde tutulan bir varlık veya portföyün belirli bir süre içerisinde, oluşabilecek en büyük zararın değerinin ölçülmesinde oldukça yaygin bir şekilde kuulanılmaktadır [3].

Son yıllarda, büyük ticari bankalarda alım-satım işlemleri ve bunlara yapılan ödemeler hızla artış göstermiş olup, daha çeşitli ve karmaşık hal almıştır. Berkowitz ve O’Brien [4], büyük bir banka holding şirketlerine ilişkin olarak, RMD yöntemiyle bankaların alım-satım risk modellerinin performansını belirlemişlerdir.

Gürsakal [5], yatırım araçlarından döviz kuru ve borsada ortaya çıkacak riskleri RMD yöntemi kullanarak tahmin etmiş ve tahmin değerleri ile hangi yatırım aracının daha riskli olduğu belirlenmiştir. Çalışmada, Riske Maruz Değer hesaplamak üzere elde tutma süresi altı ay olarak belirlenmiş ve üç farklı güven düzeyi kullanılmıștır. Analizde, Euro satış kuru ve İMKB Ulusal 30 endeksi için günlük getiri verileri kullanılmıștır. Yapılan analiz sonucunda, borsa, döviz kuruna göre daha riskli bulunmuştur. Bir başka sonuç ise, Riske Maruz Değeri açısından incelendiğinde ise, döviz kurunun borsaya göre daha düşük olduğu belirlenmiştir.

Aktaş [6], Basel II uygulamaları doğrultusunda Türkiye'de kullanılması planlanan RMD Modeli ile bankaların piyasada oluşabilecek riske karşılık ayırabileceği sermaye tutarının hedeflenen değere yaklaşıp yaklaşamayacağını araştırmıştır. Ayrıca, RMD modelinin Türkiye'deki piyasalarında kullanılmasının riskli olup olmadığını incelenmiştir. Bunu gerçekleştirmek üzere, varsayımsal bir portföy oluşturmuştur. Bu portföy içinde Devlet İç Borçlanma Senetleri (DİBS), döviz ve hisse senetlerine yer vermiştir. Daha sonar bu portföye ilişkin RMD'leri hesaplamak için parametrik RMD (VaryansKovaryans) yöntemini kullanmıştır. Elde edilen sonuçlar bir sonraki dönemde test edilmiştir. Çalışmada, 2004-2005 dönemi için günlük veriler incelenmiștir. Araștırma sonuçlarına göre, yıllar arasında ortaya çıkan değişkenlik nedeniyle, Parametrik Riske Maruz Değer (PRMD) modelinin varsayımından büyük sapmalar olduğu tespit edilmiştir. Dolayısıyla, Türkiye piyasaları açısından piyasa riskine yönelik sermaye ayrılmasında PRMD modelini kullanmanın risk taşıyacağı sonucu elde edilmiştir.

Uçkun ve Kandemir [7], İstanbul Menkul Kıymet Borsası'nda kullanılan iki endeksten seçilen hisse senetleri yardımıyla iki portföy oluşturarak, bu iki portföy üzerinde RMD uygulamış ve incelenen portföylere ilişkin risk özelliklerini risk ölçüleri dikkate alınarak karşılaştırmışlardır. Çalışma sonucunda, ele alınan portföylerin risk karakterlerinin aynı dönemlerde farklı özellikler gösterdiğini belirlenmiştir.

Demireli ve Taner [8], Euro, Altın ve ABD Doları yatırım araçlarından eşit oranda alınmış ve varsayımsal bir portföy oluşturmuşlardır. Bu portföy için de RMD ölçümlerini gerçekleştirmiştir. Parametrik olmayan Riske Maruz Değer yöntemleri arasında yer alan Monte Carlo simülasyon yöntemini kullanmışlardır. Bu yöntemin, Türkiye piyasalarında en geçerli yöntem olduğu sonucu elde edilmiştir. Ayrıca, normal dağılım varsayımını sağlaması gereken parametrik yöntemlerin tutarlı sonuçlar vermediği ve bu nedenle normal dağılım gösterme varsayımının RMD yöntemlerinde önemli bir faktör olduğu belirtilmiştir.

Eser [9], Riske Maruz Değer ve hisse senedi portföyleri için bir uygulama yapmıştır. Çalışmada, hisse senedi portföylerinin piyasa riski ölçüsü olan RMD'nin etkinliği analiz edilmiștir. RMD birçok varsayım içermesi nedeniyle farklı istatistiksel teknikleri dikkate alan yöntemlerden de yararlanmaktadır. Bundan dolayı, RMD yöntemlerinden elde edilen sonuçlar farklı olmaktadır. Bu sebeplerden dolayı Eser, iki farklı RMD yöntemini incelemiş ve yöntemlerin doğrulu olup olmadığını geriye dönük testler ile belirlemiştir.

Korkmaz ve Bostancı [10], RMD'nin belirlemesinde farklı volatilite hesaplama yöntemlerini incelemiş ve bu yöntemler arasındaki farklılıkları ortaya koymuştur. Çalışmada, İMKB 100 Endeksinin 14,5 yıl boyunca günlük kapanış değerleri analiz edilmiştir. $\mathrm{Bu}$ veriler ile farklı volatilite modelleri hesaplanmıştır. RMD hesaplamasında bu volatilite değerleri kullanılmıştır. Elde edilen sonuçları Basel II bakımından geriye yönelik test (backtesting) yöntemini kullanılarak test edilmiştir. Çalışmadan elde edilen bulgulara göre, finansal fiyat serilerinde ortaya çıkan volatilite kümelenmesi, değişen varyans, kaldıraç (leverage) etkisi, sivrilik (peakedness), EWMA ve GARCH benzeri daha gelişmiş modeller yardımıyla daha iyi modellenebildiği sonucu elde edilmiştir.

Yılmaz [11], Türk enerji piyasasının yapısını incelediği çalışmasında, elektrik iletim ve dağıtım stoklarının hesaplanmasını içeren bir portföye ilişkin olarak RMD belirlemek üzere Varyans-Kovaryans yönteminin etkinliğini analiz etmiştir. Çalışmada, portföyün volatilitesinin belirlenmesinde VaryansKovaryans yöntemi ve Üstel Ağırlıklı Hareketli Ortalama (EWMA) yöntemi kullanılmıștır.

Sahi ve Pahuja [12], geleneksel yöntemleri kullanarak, RMD yöntemlerini karşılaştırdıkları çalışmalarında, performans ölçütleri olarak Sharpe 
oranı, Treynor oranı, Jensen alfa kullanılmıştır. RMD yöntemleri olarak, tarihi simülasyon yöntemi ile risk ölçümünde normal değerden yararlanılmıştır. Çalışmada, Treynor oranı ve Jensen alfa kullanılan sonuçların farklılık gösterdiği ve Sharpe oranı ile Normal RMD için belirlenen değerin aynı olduğu belirlenmiştir.

Huang [13], ARMA süreci, asimetrik oynaklık modeli (GJR-GARCH) ve Çarpık Genel Hata Dağlımını (SGED) birleştirmeye yönelik yeni bir parametrik model önermiștir. Önerilen yeni model, ARMA (1,1) GJRGARCH (1,1) -SGED modelidir. Çalışmada incelene dört piyasaya ilişkin olarak, daha doğru risk ölçümünün sağlandığı ve daha gelişmiş bir yaklaşım olduğu ifade edilmiştir. Önerilen yeni model aşağıda belirtilen yönleri nedeniyle yeni bir yöntemdir:

i. Bir ARMA $(1,1)$ modeli kullanılarak otokorelasyon belirlenmektedir.

ii. Bir gün vadeli volatiliteyi tahmin etmede GJRGARCH $(1,1)$ kullanılmaktadır ve getirilerde kaldıraç etkisi belirlenebilmektedir.

iii. Seçilen piyasaların günlük getirilerine ilişkin ağır kuyruklar (heavy tails) modellenmek üzere eğri bir ağır kuyruk dağılımı, Çarpık Genel Hata Dağılımı kullanılmaktadır.

Çalışmadan elde edilen sonuçlar incelendiğinde, Normal Dağılıma dayanan yöntemlerinin ve Tarihsel Simülasyon yönteminin, genellikle RMD ve Beklenen Tahmini yeterince dikkate almadığı söylenebilir. Ayrıca, ağır kuyruklu dağılımlar ve asimetrik volatilite modellerinin kullanıldığı parametrik modeller, RMD ve Beklenen Kestirim değerini tahmin etmede daha doğru sonuç verdiği vurgulanmıştır. Genel olarak, çalışmada önerilen (ARMA $(1,1)$-GJRGARCH $(1,1)$-SGED) modeli, RMD‘yi aşan tek model olması nedeniyle, dört piyasanın tamamına ilişkin olarak, istenen güven aralığında, en riskli değerin risk değerleri olduğu sonucu elde edilmiştir.

Avşarlıgil vd. [14], Varyans-Kovaryans, Tarihsel Simülasyon ve EWMA gibi Riske Maruz Değer hesaplama yöntemlerini kullanmışlardır. Uygulamada, Borsa İstanbul'da işlem gören spor kulüplerine ait pay senetlerinden oluşturulan sanal iki portföy incelenmiştir. Çalışmada, Tarihi Simülasyon yönteminin en düşük tahmini verdiği belirlenmiştir. Ancak, bu yöntemin geriye dönük testler sonucunda etkinliğinin düşük olduğu sonucu elde edilmiştir. Geriye dönük test sonuçları incelendiğinde ise, en yüksek verimlilik VaryansKovaryans yöntemiyle elde edildiği ifade edilmiştir. Çalışmadan sabit varyanslılık ve normal dağılımlı olma varsayımı altında en etkili tahminin VaryansKovaryans yöntemi ile elde edildiği sonucu da elde edilmiştir.

Abdrashev [15], RMD ile İslami ve geleneksel bankaların hisse senetlerinin oynaklığını hesaplamıştır. Yapılan analizde, çeşitlilik açısından hem İslami hem de geleneksel bankalardaki yatırımcıların porföylerinin önemli ölçüde farklılık içermemekte ve farklı finansal modeller için hisse senedini etkileyen faktörlerin birbirilerine oldukça benzediğini belirtmiștir.

Handika ve Triandaru [16], en iyi RMD tahminin belirlemek üzere istatistiksel kriterleri kullanmışlar ve en iyi deneysel performansı gerçekleştirmeye çalışmışlardır. Yapılan çalışmada, RMD, GARCH (p, q) tahminini elde etmede $\mathrm{p}$ ve $\mathrm{q}$ değişkenleri kullanılmış ve hem satıcı hem de alıcı getirisine ilişkin testle belirlenmiştir. Ayrıca, Avustralya için, güven düzeyleri farklı olarak alınmış ve farklı örnekleme dönemi ele alınmış ve birbiriyle bağlantılı enerji piyasalarının oluşturduğu dört bölge kullanılmıştır. RMD yaklaşımının kullanılmasıyla, GARCH (p, q) modelinin en iyi model olduğu sonucu elde edilmiştir. Ayrıca, günlük verilerden oluşan seriler için GARCH $(\mathrm{p}, \mathrm{q})$ modelinin uygun olduğu sonucu da doğrulanmıştır.

Rankovic vd. [17], gerçek portföy oluşturarak RMD portföyünün en iyi değerini belirlemek üzere, GARCH oynaklık modelini önermişlerdir. Optimizasyon, (NSGA-II) Baskın Sıralama Genetik Algoritma kullanılarak gerçekleştirilmiştir. ABD hisse senetlerinden seçilen 40 hisse senedi incelenmiş ve ortalama-çok değişkenli GARCH ve tarihi RMD modelleri karşılaştırılmış ve ortalama RMD'nin üstün olduğu belirlenmiştir. Düşük ve yüksek her iki oynaklığa sahip örneklemler için de geçerli olduğuna ulaşmışlardır.

Bu çalışmada, Türkiye'de Borsa İstanbul'da işlem gören bazı şirketlerin verilerine volatilite tahmin modellerini uygulanması ve söz konusu şirketlere ilişkin en uygun modelin oluşturulmaya çalıșılmıştır.

\section{Materyal ve Metot}

\subsection{Riske Maruz Değer}

Risk, beklenen ile gerçekleşen değer arasındaki olumsuz (aleyhte) sapmalar olarak anlaşılmaktadır [18].

Risk, finansal veya ekonomik açıdan değerlendirilirse, bir belirsizlik durumu ya da belirsizliğin ortaya çıkardığı sonuçlar olarak ifade edilebilir.

Bir başka tanıma göre risk, karar/planlama ortamında sonuçların kestirilememesini ifade eder ve olasılık olarak tanımlanmaktadır [19].

Risk altındaki bir değeri belirtmek için;

i. Olasın bir kaybın hesaplanması gereken süre (bir gün, iki hafta, üç ay gibi) tanımlanmalıdır (Buna Riske Maruz Değer Ufku denir),

ii. Meydana gelen olayın olası kaybının miktarı tanımlanmalı, 
iii. Muhtemel kaybın yapıldı̆̆ı para birimi belirtilmelidir [20].

Literatürde çeşitli risk türleri vardır. Bunlardan bazıları finansal risk ve finansal olmayan risk; sistematik risk ve sistematik olmayan risk; kontrol edilebilir risk ve kontrol edilemeyen risk ve son olarak statik ve dinamik risk olarak ifade edilmektedir[1].

Sistematik risk kontrol altında tutulamayan olayları belirlemek üzere kullanılmaktadır. Bu tür riskler önceden bilinemez, çeşitlendirilemez ve tamamıyla önlenemezler. Sistematik olmayan risk, finansal sistemin bütününü etkileyip, belirli bir sektörü ve/ya șirketi etkilemektedir. Bu risklere müdahale etme imkanı vardır. Sistematik olmayan riski azaltmanın bir yolu portföyü çeşitlendirilmesidir. Sistematik risk ile sistematik olmayan risk, toplam riski oluşturmaktadır [21].

Dünyada bankalar diğer finansal kurumlar döviz kuru riskini ölçmek için RMD i 1990'ların ortasından itibaren kullanmaya başlamışlardır [22].

Bilgi teknolojilerinin hızlı gelişmesi, finansal araçların çeşitlilik kazanması ve işlem boyutlarının artmasıyla piyasalarda karşılaşılan risklerin türü ve boyutları da değişmiştir. Finansal kurumların oldukça kırılgan șartlarda faaliyetlerini sürdürmeleri için, ortaya çıkabilecek risklerin doğru ve kapsamlı bir şekilde ölçebilecek yöntemlere ihtiyaç duyulmaktadır [23].

Finansal piyasalar, yapısının sürekli gelişmesi nedeniyle, ortaya çıkabilecek riskin algılanması ve yönetilmesi karmaşıklaşmıştır. Bretton Woods sisteminin çöküşü ve son 20 yılda meydana gelen büyük finansal iflaslar riskin ölçülmesinin ne kadar önemli olduğunu göstermiştir. Bundan dolayı, riski ölçmek ve bunu sayısal olarak belirtmek de önem kazanmıştır. RMD bu arayışlara yönelik önemli bir araç haline gelmiştir. Bu yöntem, katlanılabilecek riski tek bir sayı ile ifade etmektedir ve finansal piyasalarında faaliyet gösteren finansal şirketler ile denetim-gözetim kurumları tarafından oldukça benimsenmiştir. İstatistiksel temel olan bu yöntemde, belirlenen bir zaman aralığ ve bir olasılıkla oluşabilecek kayıp, hesaplanan değeri aşmayacaktır [10].

RMD, koşullu ortalama için belirlenen güven aralığının alt sınırı olarak tanımlanmaktadır. "Bir günde yașanabilecek en kötü senaryo" olarak da ifade edilmektedir [24]. Riske Maruz Değer, ortaya çıkabilecek portföy kayıplarına ilişkin basit bir istatistiksel bir ölçü olarak da tanımlanmaktadır. RMD, "normal" piyasa hareketleriyle oluşan kayıpların bir ölçüsüdür [25]. RMD, istenen bir güven aralı̆̆ ve belirli bir elde tutma süresinde bir portföyün kaybedebileceği en büyük değer olarak tanımlanabilir [5].

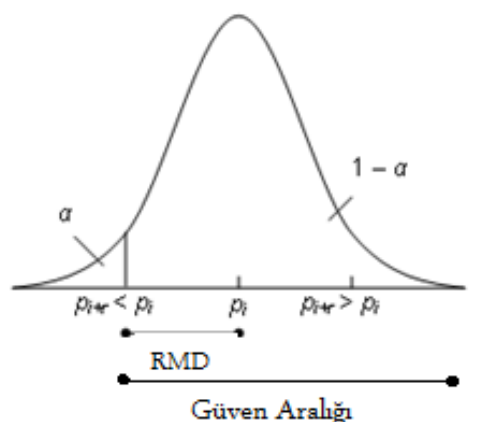

Şekil 1. Belirlenen Güven Aralığı içerisinde RMD 'in yeri [18].

Önemli bir diğer nokta, "Korelasyon (ilişki) katsayısı" dır. Korelasyon, incelenen iki değişken arasındaki aynı yönlü ya da zıt yönlü ilişki olarak tanımlanır. RMD hesaplanırken, muhtemel risk faktörleri arasındaki ilişki katsayısından yararlanılmaktadır [18].

\subsection{Riske Maruz Değer'in Matematiksel Tanımı}

RMD, piyasa riskini belirlemek üzere kullanılan ölçüdür. Finansal kuruluşlar, piyasa riski ve diğer risk türlerini tahmin etmekte ve böylece meydana gelebilecek risklere ilişkin önlem almaktadırlar. RMD, piyasada yaşanan normal dalgalanmalarla, bir portföyde ortaya çıkabilecek zararın riskini belirlemeye çalışmaktadır. RMD'nin en yaygın tanımlarından biri aşağıdaki gibi yapılmıștır [27]:

"RMD, belirli bir güven seviyesinde, bir hedef ufukta ortaya çıkabilecek en kötü kaybı ifade etmektedir" Bundan dolayı RMD, öngörülen kar/ zarar dağılımının düşük miktarını açıklamaktadır. Geçmiş dönemi içeren örneklem büyüklüğünün kullanılmasıyla, RMD'den büyük olan kayıplar sadece 1- $\alpha$ güven düzeyinde ortaya çıkmaktadır. Bu durum, Eşitlik 1'deki gibi ifade edilebilir [28]:

$$
R M D(\alpha)=\min \{x \mid F(x) \geq \alpha\}
$$

Burada; F (x), kar ve zarar üzerinde birikimli olasılık fonksiyonudur. RMD’nin grafiksel gösterimi Şekil 2'de verilmiștir.

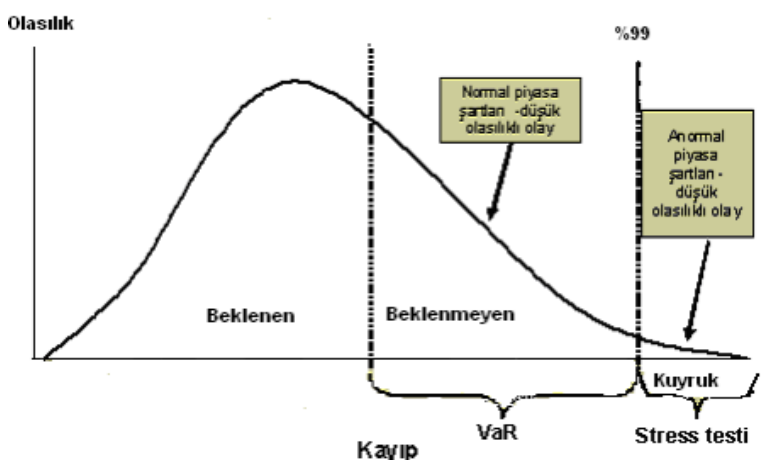

Şekil 2. Riske Maruz Değer [29].

Riske Maruz Değer modelleri, bankaların taşıdığı riskleri ölçmede ve bu risklere karşılık bulundurulması gerekli olan sermaye tutarının 
belirlenmesinde çok daha doğru sonuçlar sunmaktadır. Ayrıca uygulama koşullarında uyulması gereken standartlar olması nedeniyle kurumlar ya da bankaların karşılaştırılmaları daha güvenilirdir. Bankalar Komitesi tarafından belirlenen koşullara göre RMD’yi \%99 güven aralığı ve günlük veriler için veri seti en az 250 iş gününe ait olmalı ve elde tutma süresi de en az 10 gün olması gerekmektedir.

RMD yaklaşımının hesaplanma süreci aşamaları aşağıda sıralanmıştır:

i. Piyasa fiyatı yardımıyla portföyler değerlendirilir,

ii. Risk faktörlerinin değişkenliğin ölçülür ve elde tutma süresinin belirlenir,

iii. Güven aralığı belirlenir ve veriler kullanılarak, oluşabilecek en yüksek kayıp tutarları hesaplanır,

iv. Sonuçlar raporlanır [23].

Riske Maruz Değer yöntemi aşağıdaki şekilde siralanabilir [30]:

1) RMD, sadece "normal" piyasa koşullarında ortaya çıkabilecek zararlar bir miktar güven seviyesi ile sağlamaktadır. Başka bir anlatımla, RMD, \%95 olasılıkla karşılaşılabilecek en kötü durumu ifade etmektedir. RMD, aşırı olarak değerlendirilebilecek sartlarda mutlak olası kayıplara yönelik bir tahmin vermez.

2) RMD alt katkı sağlamadığından tutarlı bir risk ölçümü değildir. Alt katkı sağlamayan bir risk ölçümü, yapılan portföy çeşitlendirmesinin iyi bir seçenek olmadığını ileri sürer. Bunun nedeni, portföy riski, bireysel varlıklara ilişkin risklerin toplamından daha büyüktür.

3) RMD'de elde tutma süresi boyunca portföy pozisyonlarının değişmediği varsayılmaktadır. Bundan dolayı, 1 günlük RMD belirlemek için, zamanın karekökünün kullanılmasıyla, bir çoklugün RMD ayarlanması, portföy pozisyonlarındaki ortaya çıkan değişimler için uygun değildir. $\mathrm{Bu}$ durum da, piyasa koşullarında ortaya çıkacak değişmeye cevap olarak alım-satım zamanının değişebilme ihtimalini dikkate almamaktadır.

4) RMD modelleri tarihsel verilere dayanmaktadır. $\mathrm{Bu}$ nedenle yakın geçmiş, gelecekteki rassallığa ilişkin iyi bir yansıması olduğu varsayılmaktadır.

\subsection{Riske Maruz Değer Çeşitleri}

Riske Maruz Değer, hemen hemen tüm finansal kurumlar tarafından günlük risk ölçümünde kullanılmaktadır. Genel olarak üç şekilde ele alınmaktadır.

\subsubsection{Göreceli Riskteki Değer (Relative Value at Risk)}

Göreceli Riskteki Değer; riski, önceden belirlenmiş bir portföyün başarısı nispetinde ölçmektedir. Bu durum yatırımı yönetenler de dahil olmak üzere birçok kurumsal yatırımcıyı da ilgilendirmektedir. Bunun nedeni, yatırım araçlarının performanslarının hedeflenen bir portföyle karşılaştırılmasıdır [31].

\subsubsection{Marjinal Riskteki Değer}

RMD belirlenirken, bir portföyün pozisyon değerlerinin değişmediği varsayımı yapılmaktadır. Ancak, yatırımcılar ellerinde olan portföylerin RMD tutarlarını ve portföylerinde yer alan yatırım araçlarına ilişkin belirlenen ağırlıkları değiştirebilmektedir. Ayrıca, portföylerine yeni yatırım araçlarının da eklenmesi mümkündür. Başka bir anlatımla, Marjinal Riske Maruz (Marginal Value at Risk) Değer Yöntemi, portföyde yer alan yatırım araçlarının ağırlıklarının değiştirilmesi ya da çeşitlendirilmesi durumunda, portföye ilişkin Riske Maruz Değerinde oluşan değişme belirlenebilmektedir. Denetim riskini ortadan kaldırmak ve getirileri artırmak üzere Marjinal Riske Maruz Değer yöntemi standart araçlardan biri haline gelmiştir [8].

\subsubsection{Farksal Riskteki Değer}

Farksal Riskteki Değer (Differantial Value at Risk), Marjinal Riskteki Değer kavramı ile yakından ilgilidir. Bir pozisyonu tamamen ortadan kaldıran ve risk portföyünde meydan gelen farkları ölçen Marjinal Riskteki Değer'dir. Pozisyonun portföy içindeki ağırlığını dikkate alınmasını ve oluşan tüm küçük değişikliklerin etkisini ölçülmesi Farksal Riskteki Değer ile yapılmaktadır[31].

\subsection{Riske Maruz Değer Hesaplamasında Kullanilan Parametreler}

RMD analizinde en çok dikkat edilmesi gerekli unsur risk faktörüdür. Risk faktörü, ortaya çıkabilecek değişme olasılıklarını belirler ve değişim oranını açıklar. Risk faktöründeki oluşabilecek değişmelerin seçilmesinde etkili olan unsurlar; risk dönemi olarak ifade edilen elde tutma süresi, örneklem dönemi, istenen güven düzeyi ve volatilitedir [7].

\subsubsection{Elde Tutma Süresi}

Elde tutma süresi (Holding Period), bir yatırımcının yapmış olduğu yatırımın elde tutulması süresi ya da bir teminatın satın alınması ve satılması arasında geçen süredir. Uzun dönemde elde tutma süresi, finansal bir varlığın satın alındığı ve satıldığı zaman arasında geçen süredir. Opsiyon pozisyonunda kısa 
elde tutma süresi, bir yatırımcının menkul kıymetleri geri alması ile kısa pozisyonu kapatmak için borç aldığı kişiye teslim etmesi arasındaki süredir. Yatırımın elde tutma süresi, sermaye kazanç veya kayıplarının vergilendirilmesinde kullanılmaktadır. Bir yıl ya da daha uzun bir süre uzun vadeli bir tutma süresini ifade etmektedir. Bir yıldan daha az süreli yatırımlar kısa vadeli olarak adlandırılır [32].

Elde tutma süresi, incelenen finansal varlığın nake çevrilebilme durumuna (likiditesine) göre değişim göstermektedir. Uluslararası Ödemeler Bankası (Bank of International Settlement (BIS)), 10 günlük sürenin elde tutma süresinin olarak belirlenmesini önermektedir. Türkiye'de ise Bankacılık Düzenleme ve Denetleme Kurumu (BDDK) hazırladığ tebliğe göre (Kasım 2006 tarih ve 26335 sayılı resmi gazetede yayımlanan); bankaların \% 99 güven aralığını ve elde tutuma süresi olarak en az 10 iş günü almasını öngörmektedir. RMD hesaplarken, elde tutma süresi zamanın karekökü olarak tanımlanır ve aşağıdaki gibi hesaplanmaktadır [33]:

Elde tutma süresi 1 gün olursa: : $\sqrt{1}=1$

Elde tutma süresi 10 gün olursa: $\sqrt{10}=3,162278$

Elde tutma süresi 252 gün olursa : $\sqrt{252}=15,87451$ şeklinde belirlenmektedir.

\subsection{2. Örnekleme Periyodu}

RMD hesaplanmasında dikkate alınan dönem, zamanla fiyat değişmelerinin olabileceği ve oluşacak volatilite ve korelasyonun hesaplanabileceği gözlem dönemidir (Sampling Period). BASEL komitesi bir yıllık gözlem döneminin seçilmesini önermektedir. Gözlem döneminin oldukça kısa seçilmesi nedeniyle, risk ölçüm sonuçlarının fiyatlarda meyana gelen değişmeye karşı oldukça duyarlı olacaktır [33].

\subsubsection{Güven Aralığı}

Güven aralığı(Confidence Interval), RMD yöntemini uygularken, yapılan hesaplamanın güvenini vermektedir. Güven düzeyi konusunda BASEL Komitesi \%99 güven düzeyinin ve tek yönlü güven aralığının kullanılmasını önermektedir. Güven düzeyinin yüksek olması ile RMD de o derece yüksek bir olacaktır. BDDK, güven düzeyinin $\% 99$ olarak alınmasıyla, riskin ölçülmesini benimsemiştir. $\mathrm{Bu}$ güven aralığının değeri belirlenirken, standart normal dağılım tablosundan yararlanılmaktadır (z: standart normal dağılım tablo değeri olup; \%95 güven düzeyi için 1,65 ve \%99 güven düzeyinde 2,33 değerini almaktadır [33].

\subsubsection{Volatilite}

Volatilite, belirli bir zaman biriminde bir tek varlık ya da portföyün sağladığı getirilerin standart sapmasıdır. Risk yönetimi araçları açısından günlük dalgalanmalar esas alınmaktadır. RMD ile riskin ölçülmesinde volatilite en önemli unsur olduğu belirtilmektedir. Günlük dalgalanma hesaplandıktan sonra, yıllık için başta olmak üzere diğer zaman dilimleri için de volatilite hesaplanması mümkündür [37].

Risk yönetimini değerlendirmek ve genel olarak portföyü yönetmek için de Volatilite kullanılmaktadır. Finansal kuruluşlar açısından yönetilen varlıkların volatilitesinin mevcut değerinin bilinmesi kadar, gelecekteki değerlerinin ne olacağının tahmin edilebilmesi olukça önemlidir. Volatilitenin tahmin edilmesi, opsiyon ticareti ve portföy yönetimini ilgilendiren kurumlar için bir hayli önemlidir [47].

Portföy risk faktörlerinin değişkenliği, portföy volatilitesi ile ölçülmektedir. Hesaplamalar yapılırken, günlük oransal fiyat değişmelerine ilişkin yıllık standart sapmaları dikkate alınmaktadır. Portföy gelirlerine ilişkin volatilite değeri, portföyün risk faktörleri arasında olan varyans ve kovaryansa ve bir varlığın risk faktörlerine karşı duyarlıdır. Volatiliteyi hesaplamada farklı yöntemler söz konusudur [7].

Elde tutulan pozisyon sayısı T için RMD değeri Eşitlik 2'deki gibi belirlenmektedir [34]:

$$
\mathrm{RMD}=\text { Portföy Değeri } \mathrm{x} \sigma_{p} \times \sqrt{t} x \alpha
$$

Burada;

$\sigma_{p}$ : Porföyün volatilitesi (standart sapma)

$\mathrm{t}$ : Elde tutma süresi

$\alpha$ : Güven aralığı (tek yönlü z istatistiği)'dır.

RMD tahminini belirlemede volatiliteyi modellemede, Engle (1982) tarafından geliștirilen, Auto Regressive Conditional Heteroscedasticity (ARCH) modeli kullanılmaktır. $\mathrm{Bu}$ modeller daha sonra Bollerslev (1986) ve Taylor (1986) tarafından genelleştirilmiştir. ARCH modelleri, oynaklık kümelenmesinin nasıl olduğunu belirlemektedir. Portföyler bakımından, risk yönetimi çok değișkenli GARCH modellerinin kullanılmasını gerektirmektedir. Ancak, risk ölçümü için bir araç olarak tek değişkenli modeller kullanılmakta ve daha doğru volatilite tahminleri vermektedir [35].

\subsection{Riske Maruz Değerin Kullanım Alanları}

Riske Maruz Değer'in kullanıldığı alanlar așağıda verilmiştir [36]:

1) Normal dağlım göstermeyen getirilere ilişkin bir ölçü olarak,

2) Yüksek güven düzeyi ile tahminlerde ölçüt olarak,

3) Toplam risk ölçütü olarak,

4) Stres testi için,

5) Finansal kurumlar açısından uygun bulunan risk ölçütü olarak,

6) Basel Anlaşmalarında yer verilen düzenleme için bir araç olarak. 


\subsection{Riske Maruz Değer Modelinin Avatajı ve Dezavantajları}

RMD'nin en önemli avantajı, yöntemin sade ve uygulanmasının kolay olmasıdır. Yöneticiler veya diğer kişiler, teknik bilgiye sahip olmadan da, riskleri kolayca anlayabilir ve yorumlayabilir. Ayrıca, RMD portföyünde yer alan bireysel varlıklara odaklanmak zorunda değildir ve bir portföy için net bir sonuç verebilmektedir.

Buna karşılık RMD’nin dezavantajı, tarihsel simülasyon yöntemi dışında tüm RMD yöntemlerinin normal dağılım varsayımına dayanmasıdır. Ancak, iade normal olarak dağıtılmamakta ve piyasada çok fazla etkili olay söz konusudur. Meydana gelen olağanüstü durumlar, risklerin küçümsenmesine veya hafife alınmasına neden olmaktadır [37].

\section{6. Riske Maruz Değer Yaklaşımları}

RMD'nin gerçekte hesaplanması konusunda bir tartışma sözkonusudur. 1990'ların ilk yıllarından bu yana üç ana yöntem ileri sürülmüştür. Bunlar:

i. Varyans-Kovaryans yöntemi (Parametrik yöntem )

ii. Tarihsel Simülasyon yöntemi

iii. Monte Carlo Simülasyonudur.

Tarihsel Simülasyon yöntemi ile Monte Carlo Simülasyonu parametrik olmayan yöntemdir.

$\mathrm{Bu}$ yöntemlerin her birinin güçlü ve zayıf yönleri vardır. Hangi yöntemin en iyi olduğu hakkında bir fikir birliğine ulaşılamamasının nedeni, RMD metodunun amacına ilişkin konularda meydana gelen farklılıklardır. Yöntemin seçilmesinde, incelenecek varlıkların sayısı ile türü ve RMD’nin gerçekleştirmesi gereken hedef önemli rol oynamaktadır. Risk yöneticisi, her bir bireysel duruma ilișkin var olan çeşitli yöntemler arasındaki dengeleri gözetmekte ve ortaya çıkan durumları karşılaştırmaktadır [28].

Parametrik yöntemler, varlık getiri verilerinin dağlımının normal olduğunu varsayar ve bu varsayımla bir güven düzeyi belirlemektedir. Parametrik olmayan yöntemler varlık getirilerinin dağlımıyla ilgili olarak herhangi bir varsayıma dayanmamaktadır [8].

RMD'nin geniş kullanım alanı olmasının nedeni olarak tüm portföy riskini tek bir sayı ile ifade etmek şeklinde vurgulanmaktadır [38].

Yapılan çalışmalarda yaygın şekilde kullanılan üç farklı yaklaşım izleyen alt kesimlerde sunulmuştur. $\mathrm{Bu}$ yaklaşımlar ile belirlenen RMD değerlerini etkileyen avantaj ve dezavantajlar vardır. Yaklaşımların varsayımları getirilerin özellikleri ile farklı şekillerdedir [39].

\subsubsection{Varyans Kovaryans Yöntemi}

J.P Morgan tarafından popüler hale getirilen VaryansKovaryans (delta-normal) modelinin varsayımı, piyasa değişkenlerine ilişkin günlük geometrik getiri değerlerinin ortalaması sıfır olan normal dağıldığıdır. Geçmiş dönem değerleri, ortalamaları, standart sapmaları, korelasyonları belirlemede kullanılmaktadır [40]. yöntemde zaman serisinin geçmiş dönem verileri kullanılır ve portföyün getirilerine ilişkin volatilite ve korelasyonlar hesaplanmaktadır. Bir portföy için RMD hesaplanmasında kullanılan formül Eşitlik 3'de verilmiştir.

$$
R M D_{p}=\sqrt{V * \rho * V^{T}}
$$

formülü ile hesaplanmaktadır.

$\rho$ : Korelasyon matrisi

Eşitlik 3'te yer alan $V$ vektörü Eşitlik 4'te belirtilmiştir:

$$
V=\left[\begin{array}{c}
V_{1} \\
V_{2} \\
\cdot \\
\cdot \\
\cdot \\
V_{N}
\end{array}\right]=\left[\begin{array}{c}
P_{1} \cdot \sigma_{1} \cdot z_{\alpha} \\
P_{2} \cdot \sigma_{2} \cdot z_{\alpha} \\
\cdots \\
\cdots \\
P_{N} \cdot \sigma_{N} \cdot z_{\alpha}
\end{array}\right]
$$

$\mathrm{Bu} \mathrm{V}$ vektörü, $\rho$ korelasyon matrisi ile çarpılır ve portföyün RMD'si Eşitlik 5'de gösterildiği şekilde bulunur [41].

$$
\begin{aligned}
& \operatorname{RMD}_{p} \\
& =\left\{\left[V_{1} V_{2} \ldots V_{N}\right]\left[\begin{array}{rrrr}
1 & \rho_{12} & \ldots & \rho_{1 n} \\
\rho_{21} & 1 & \ldots & \rho_{2 n} \\
\ldots & \ldots & \ldots & \ldots \\
\rho_{N 1} & \rho_{N 2} & \ldots & 1
\end{array}\right]\right\}^{1 / 2}
\end{aligned}
$$

Yöntemin uygulanabilmesi için; her bir risk faktörüne ait volatilitenin ve risk faktörlerinin arasındaki korelasyonun bilinmesi gerekmektedir. JP Morgan tarafından geliştirilen Risk Ölçümü (RiskMetrics) Varyans-Kovaryans modelini kullanmaktadır ve portföy karlılığının normal dağıldığı varsayımı vardır. Bu ölçüm, portföyün değerinde oluşacak değişiklikler logaritmik fiyat değişiklikleri şeklinde gerçekleştirilmektedir [7].

\subsubsection{Tarihi Simülasyon Yöntemi}

Tarihsel simülasyon, RMD tahmininde en çok kullanılan yöntemdir. Bu yaklaşım, portföy dağılımı hakkında herhangi bir varsayımına dayanmamaktadır. $\mathrm{Bu}$ nedenle, RMD hesaplama işlemlerini oldukça kolay hale getirmektedir [42]. Tarihsel simülasyon yönteminde varyans- kovaryans hesaplaması yapılmamaktadır. Bundan dolayı, doğrusal /ya da doğrusal olmayan varlık getirilerini 
belirlenmesinde bu yöntem kullanılmaktadır. Tarihsel simülasyon yönteminde, geçmiş dönem verileri kullanılarak, çeşitli senaryolar oluşturulmaktadır. Daha sonra, belirlenen güven düzeyinde en düşük getiriyi belirlemede düzenli bir tarihsel portföy getiri serisi oluşturulmaktadır. Bu yöntemde, ilk olarak oluşturulan portföyde yer alan her bir varlığın geçmiș dönem getirisi belirlenir. Daha sonra portföyün getirisini belirlemek için portföydeki her bir aktifin getirisi portföydeki ağırlığa göre çarpılır. Ardından portföy getiri serisi en düşük değerden en yüksek değere göre sıralanır. Böylece, her getiriye ilişkin yüzdelik seri oluşturulur. Tüm bu işlemlerden sonra, güven düzeyine karşılık olan yüzde değer, bu yüzdeye karşılık gelen getiri değeri de, RMD olarak belirlenir [37].

Tarihsel Simülasyon yöntemi, parametre dışı Riske Maruz Değer şeklinde de adlandırılmaktadır. Bu yöntem, Monte Carlo Simülasyon yönteminin daha basit hale getirilmiş bir şeklidir ve doğrusal ya da doğrusal olmayan bütün araçlara uygulanmaktadır. Tarihi simülasyon yönteminde, geçmiş 252 güne ilişkin varlık getirileri zaman serisine, mevcut portföy ağırlıkları uygulanmaktadır. Buna göre model Eşitlik 6'da verilmiştir:

$$
R_{p, k}=\sum_{i=1}^{N} w_{i, t} R_{i, t}
$$

$\mathrm{k}:(1,2, \ldots, \mathrm{t})$,

w: portföy içinde yer alan risk faktörlerinin günümüzdeki ağırlıkları,

R: getiri değişimlerini göstermektedir.

Portföyün güncel ağırlık katsayıları dikkate alınarak t zamanı getirisinde oluşan değişmeler ile, olası portföyler hesaplanmaktadır. Bunun sonucunda da $\% 95$ veya \%99 güven düzeyinde RMD sonuçları elde edilmektedir [33].

\subsubsection{Monte Carlo Simülasyonu Yöntemi}

Monte Carlo simülasyon yöntemi, yarı-parametrik bir yöntemdir. $\mathrm{Bu}$ yöntem ile tarihsel simülasyon yöntemi arasında bazı benzerlikler vardır. Ancak, iki yönteme ilişkin temel farklılık, Monte-Carlo simülasyon yönteminde piyasa faktörlerinde çok sayıda (binlerce-onbinlerce) varsayımsal değișmeleri oluşturmak için rasgele sayı üreteci kullanılmaktadır.

$\mathrm{Bu}$ üreteçler daha sonra da mevcut portföy üzerinde çok sayıda varsayımsal portföyün kâr ya da zararı ve gerçekten oluşturulan portföyün kâr ya da zararın dağılımını belirlemek için kullanılır. Son olarak, risk altındaki değer bu dağılım yardımıyla belirlenmektedir [25]. Monte Carlo modelleri esnektir. Örneğin, bağımlılığın modellenmesinde bir kopuladan yararlanılabilir. Böylece, her türlü marjinal risk faktörü getirisinin dağılımı oluşturulabilmektedir [43].

\subsubsection{Yöntemlerin Karşılaştırılması}

RMD yöntemleri, opsiyon riskleri ve opsiyona benzer araçlar, uygulamanın kolaylığı, sonucun açıklamasının kolay olması, varsayımlarda ortaya çıkan değişmelerin etkisinin analiz edilmesindeki esneklik ve sonuçların güvenilirliği bakımından farklılıklar göstermektedir. Risk yöneticisinin en önemli gördüğü boyut ile en iyi seçim yapılmaktadır. Kısa dönem için seçenekleri dikkate almadan portföyler değerlendiriliyorsa, varyans-kovaryans matrisi yöntemi, oldukça iyi sonuçlar vermektedir. RMD, istikrarlı ve önemli tarihsel verilerden oluşan bir risk kaynağı için hesaplanıyorsa, sağladığı tahmin açışınsan, tarihsel simülasyon yöntemi daha iyi sonuçlar sunmaktadır.

Monte Carlo Simülasyonu yönteminde geçmiş verilere dayalı bir dağıtım uygulanarak, gelecekteki getiri değerleri tahmin edilir. Ancak parametrik yöntemin aksine, Monte Carlo simülasyonu normal dağılım varsayımında bulunmamaktadır. Bunun nedeni, tarihsel verilerin dağılımı yaklaşık olarak belirlemede birkaç kez rassal örneklem alınmaktadır. Bununla birlikte, bu rassal örnekleme, yoğun bir hesaplama yapmaya neden olur ve bundan dolayı, gerçek zamanlı bir uygulama yapmak zorlaşmaktadır.

Tarihsel verilerin durağanlık koşulunu sağlamaması ve normallik varsayımın sorgulanabilir olmasından dolayı, Monte Carlo simülasyonları uzun süreler boyunca doğrusal olmayan portföyler için en genel hesaplamada en iyi sonuçları vermektedir [44].

Yukarıda sözü edilen üç yöntemin karşılaştırılması Tablo 1'de verilmiştir [45].

Buna göre;

- Hesaplama hızı ve risk yoğunluklarını belirlemede Parametrik RMD yöntemi (PRMD) daha güçlüdür ve doğrusal olmayan enstrümanlara daha zayı uygunluk sağlamaktadır.

- Monte Carlo ve Tarihi Simülasyon modelleri doğrusal enstrümanlar üzerinde RMD'yi hesaplamada daha güçlüdür.

- Tarihi Simülasyon modeli normal dağılımlı olmayan verileri daha başarılı bir şekilde modelleyebilmektedir.

\section{Bulgular}

\subsection{Uygulama}

Çalışmanın uygulama bölümünde, Zorlu Enerji Elektrik Üretim A.Ş., (BİST 50 endeksi kapsamında), Ak Enerji Elektrik Üretim A.Ş. (BİST 100 endeksi kapsamında)ve Aksu Enerji ve Ticaret A.Ş (Borsa İstanbul'da işlem gören şirketler arasında) için 2008- 
Tablo 1. Riske Maruz Değer yöntemlerinin karșlaștırılması

\begin{tabular}{|c|c|c|c|}
\hline & Varyans-Kovaryans & TarihiSimülasyon & Monte Carlo Simülasyonu \\
\hline $\begin{array}{l}\text { Hesaplama } \\
\text { Kolaylığ }\end{array}$ & Yüksek & Yüksek & Düşük \\
\hline Uygulama Kolaylığı & Yüksek & Yüksek & Düşük \\
\hline $\begin{array}{l}\text { Üst } \quad \text { Düzeye } \\
\text { Raporlanabilirlik }\end{array}$ & Düşük & Yüksek & Düşük \\
\hline $\begin{array}{l}\text { Türev Ürünleri Ele } \\
\text { Alma Biçimi }\end{array}$ & Düşük & Yüksek & Yüksek \\
\hline $\begin{array}{l}\text { Beklenmedik } \\
\text { Olayları Dikkate } \\
\text { Alma }\end{array}$ & Düşük & Düşük & Yüksek \\
\hline Kisitlar & $\begin{array}{l}\text { Tamamı ile normal dağılım } \\
\text { varsayımına dayanması } \\
\text { Olağandışı piyasa } \\
\text { hareketlerini kapsaması } \\
\end{array}$ & $\begin{array}{c}\text { Geçmiş verilerin temininde zorlukyaşanması } \\
\text { Kullanılan veri setinde olağandışı fiyat } \\
\text { hareketlerinin olmamasından dolayı tüm } \\
\text { olası hareketleri kapsaması } \\
\end{array}$ & $\begin{array}{l}\text { Modelleme riskinin yüksek oluşu } \\
\text { Karmaşı hesaplamalara yer } \\
\text { verilmesi ve zor anlaşılır olması }\end{array}$ \\
\hline Ürtünlükler & $\begin{array}{l}\text { Doğrusal getirisi bulunan } \\
\text { portföylerde yüksek başarı }\end{array}$ & $\begin{array}{c}\text { Kavramsal olarak kolay ve anlaşılır olması } \\
\text { Her türlü pozisyona uyarlanması }\end{array}$ & $\begin{array}{c}\text { Karmaşık ve doğrusal olmayan } \\
\text { pozisyonların ele alınmasın-da } \\
\text { bașarı }\end{array}$ \\
\hline
\end{tabular}

Tablo 2. Enerji sektöründe yer alan üç șirketin 2008-20018/05 yllları arasındaki aylık verilerine ait tanımlayıcı istatistikleri

\begin{tabular}{cccccccccc}
\hline $\begin{array}{c}\text { Şirket } \\
\text { Adı }\end{array}$ & $\begin{array}{c}\text { Minimum } \\
\text { Değer }\end{array}$ & $\begin{array}{c}\text { Maksimum } \\
\text { Değer }\end{array}$ & Medyan & $\begin{array}{c}\text { Standart } \\
\text { Sapma }\end{array}$ & Ortalama & Çarpıklık & Basıklık & $\begin{array}{c}\text { Jarque- } \\
\text { Bera }\end{array}$ & $\begin{array}{c}\text { p } \\
\text { Değeri }\end{array}$ \\
\hline AKENR & 0.72 & 18.40 & 1.68 & 4.12 & 3.63 & 1.78 & 2.38 & 91.3552 & 0.000 \\
AKSUE & 1.75 & 13.53 & 5.7 & 2.95 & 6.36 & 0.61 & -0.47 & 8.90246 & 0.011 \\
ZOREN & 0.26 & 5.95 & 1.7 & 1.08 & 2.09 & 1.58 & 2.39 & 77.5401 & 0.000 \\
\hline
\end{tabular}

2018:05 dönemine ilişkin aylık kapanış fiyatları verileri analiz edilmiştir. Tanımlayıcı İstatistikleri Tablo 2'de verimiştir. Verilerin analizinde Eviews 8.0 ve Minitab 17 paket programlarından yararlanılmıştır.

Tablo 2 incelenecek olursa, incelenen şirketler arasında en küçük değer Zorlu Enerji için hesaplanmıştır. En yüksek değerin ise Ak Enerji'ye ait olduğu görülmektedir. Ak Enerji'de medyan değerinin 1.63 (medyan, en küçük değere çok yakındır) olduğu ve bu nedenle incelene dönem içerisinde genellikle düşük değerlerin gözlemlendiği sonucu ortaya çıkmaktadır. Aksu Enerji için medyanın değeri 5.7'dir ve bu değer aritmetik ortalamaya yakın bir değerdir. Zorlu Enerji için ise medyanın değeri 1.7'dir. Ak Enerji'de olduğu gibi medyan değerinin en büyük değerden uzak ve en küçük değere yakın olduğu görülmektedir. Aritmetik Ortalama değerinin en yüksek olduğu şirket Aksu Enerji'dir. Düşük olması beklenen standart sapma Ak Enerji için diğer şirketlere kıyasla, yüksektir.

Çarpıklık değerleri incelenecek olursa, üç şirket verilerine ilişkin çarpıklık katsayısı değerinin sıfırdan büyük olması nedeniyle, verilerin pozitif çarpık olduğu ve dağılımın uzun sağ kuyruğa sahip olduğu ifade edilebilir. Ak Enerji ve Zorlu Enerji'nin çarpıklık katsayısı değerleri normal dağılımınkine göre biraz uzakken; Aksu Enerji'nin kapanış fiyatı verilerinin simetrisi normal dağılıma yakındır. Basıklık değerleri 3'ten küçük olduklarından, incelenen kapanış fiyatı serilerinin normal dağılımla karşılaştırıldığında, daha basık oldukları ifade edilebilir.

Verilerin normal dağlım gösterip göstermediğini belirlemek üzere Jarque-Bera test istatistiği kullanılmaktadır. Dağılımın Normal dağılım olduğunu ifade eden sıfır hipotezi altında, Jarque-Bera test istatistiğinin dağılımı iki serbestlik dereceli $\chi^{2}$ dağılımdır.

Sıfır hipotezi altında Jarque-Bera test istatistiğinin gözlenen değerden (mutlak değer) büyük olması olasılığı p değeridir. $\mathrm{p}$ olasılık değeri, alfa anlamlılık düzeyinden küçük olması durumunda sıfır hipotezi reddedilmektedir [46]. Analizde verilerin normal dağılımlı olup olmadığını test etmede kullanılan Jarque-Bera test istatistiğine ilişkin olasılık değerleri anlamlılık dzüeyi olan 0.05 'ten küçük olduğundan, sifır hipotezi reddedilmektedir.

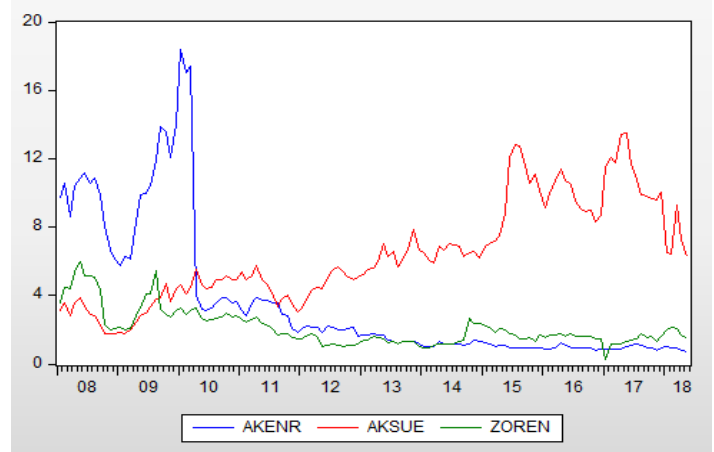

Şekil 3. Şirketlerin değişim grafiği

Üç firmaya ilişkin incelenen dönem içerisindeki değişimler incelenmiştir. İncelenen üç şirket için 2008 yılında ortaya çıkan ekonomik krizin etkileri açık bir şekilde görülmektedir. Bu üç şirket aynı sektör içerisinde yer almalarına rağmen, Ak Enerji ve Zorlu Enerji'ye ilişkin veriler, 2010 yılı ve sonrasında, birlikte azalma eğilimi göstermektedir. Aksu Enerjiye ilişkin veriler, incelenen dönemde artış göstermiştir.

Ak Enerji'ye ilişkin, 2008-2018 yılları arasındaki değişim Şekil 4'te verilmiştir. Buna göre, 2008 yılında ortaya çıkan ekonomik krizin olumsuz etkisinin olduğu ve 2009-2010 döneminde kısa süreli de olsa 
bir artışı meydana geldiği belirlenmiştir. 2010 yılından itibaren ise azalma görülmektedir.

Aksu Enerjinin 2008-2018 yılları içerisindeki değişimi Şekil 5’te verilmiştir. Şekil 5, Aksu Enerji şirketine ilişkin veriler de 2008 krizinden olumsuz şekilde etkilenmiştir. Fiyatlarda ortaya çıkan kısa süreli düşüşler görülmesine karşın, seride genel olarak artan bir trende sahip olduğu söylenilebilir. Zorlu Enerji için grafik Şekil 6’da verilmiştir.

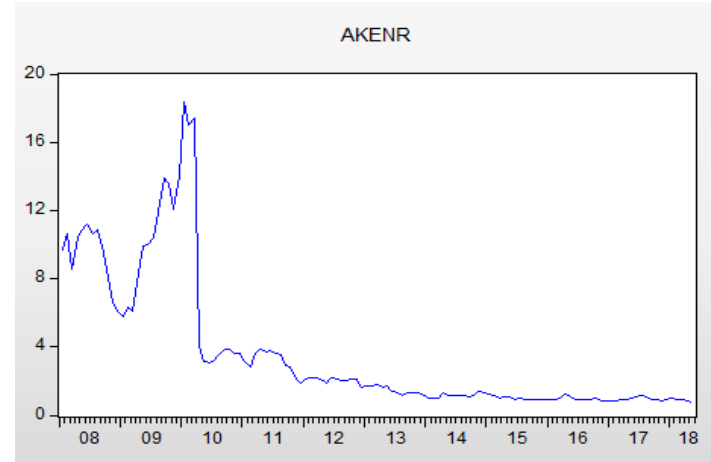

Şekil 4. AKENR grafiği

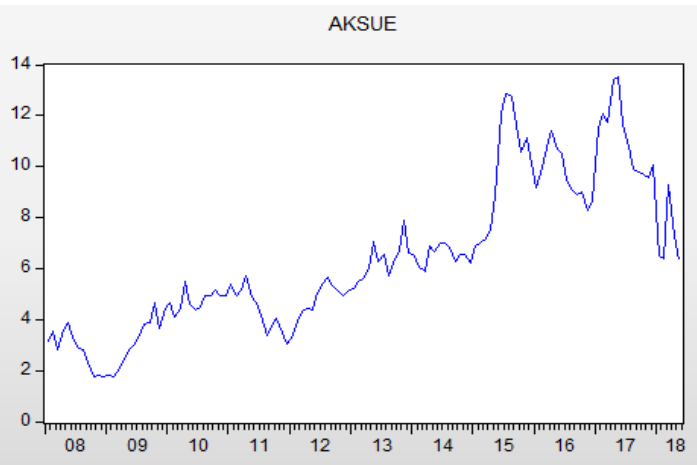

Şekil 5. AKSUE grafiği

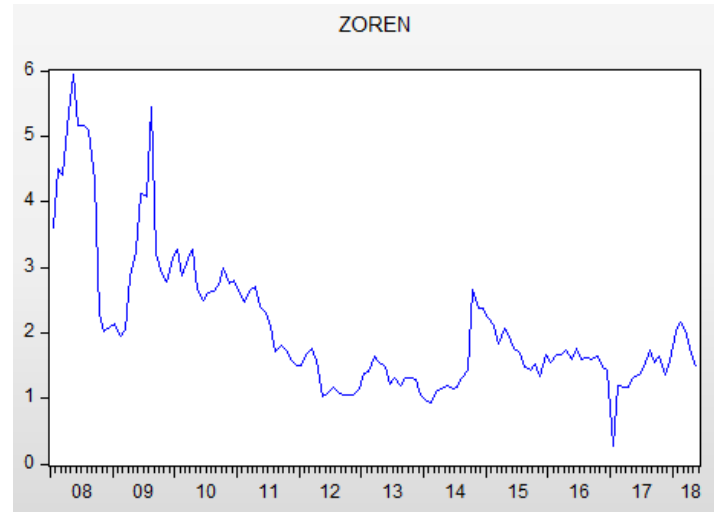

Şekil 6. ZOREN grafiği

Zorlu Enerji de bir çok firmanın yaşadığı şekilde, 2008 krizinden olumsuz bir şekilde etkilenmiştir. 2010 yılına kadar artış görülse de sonrasında verilerin azalan bir trend gösterdiği ifade edilebilir.

AKENR, AKSUE ve ZOREN verilerine ilişkin durağanlığın olp olmadığını belirlemede yararlanılan birim kök testi sonuçları Tablo 3'te verilmiştir.
Tablo 3. AKENR, AKSUE ve ZOREN verileri için Birim Kök Testi

\begin{tabular}{ccc}
\hline $\begin{array}{c}\text { Şirket } \\
\text { Ad } 1\end{array}$ & $\begin{array}{c}\text { ADF- Test İstatistiği: } \\
\text { t değeri }\end{array}$ & $\mathrm{p}-$ değeri \\
\hline AKENR & -2.127922 & 0.2342 \\
AKSUE & -1.769264 & 0.3942 \\
ZOREN & -2.455045 & 0.1291 \\
\hline
\end{tabular}

Tablo 3 incelendiğinde, AKENR AKSUE ve ZOREN için düzeyde verilerine yapılan birim kök testi sonuçlarına göre, "İncelenen zaman serisinde birim kök vardır (Seri durağan değildir)” şeklinde ifade edilen sıfır hipotezi kabul edilmektedir (olasılık değerleri 0,05 'ten büyük olduğundan). Buradan; AKENR, AKSUE ve ZOREN'e ilişkin zaman serisi verileri için durağanlık koșulu sağlanmamaktadır. Serilerin birinci farkları alınarak elde edilen grafikler Şekil 7'de verilmiştir.

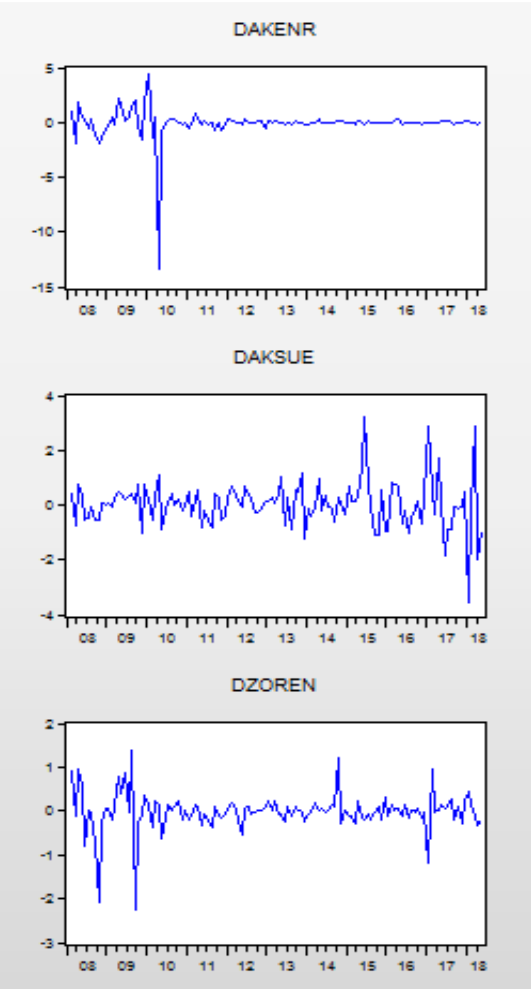

Şekil 7. Durağanlık sınaması

Şekil 7 incelendiğinde, Üç şirkete ilişkin veriler için birinci dereceden fark alınmasıyla durağanlığın sağlandığı görülmektedir. Birinci farklar seriş için yapılan birim kök testi sonuçları Tablo 4'te verilmiștir.

Tablo 4. Birinci farkları alınmış AKENR, AKSUE ve ZOREN serisi için Birim Kök Testi sonuçları

\begin{tabular}{ccc}
\hline Şirket Adı & ADF- Test İstatistiği: $t$ değeri & p-değeri \\
\hline$\Delta$ (AKENR) & -9.929843 & $<0,01$ \\
$\Delta$ (AKSUE) & -10.80613 & $<0,01$ \\
$\Delta$ (ZOREN) & -15.19390 & $<0,01$ \\
\hline
\end{tabular}

Tablo 4 incelendiğinde; üç şirkete ait veriler için de birinci farklar alınmasıyla, durağanlığın sağlandığı görülmektedir. 
Tanımlayıcı istatistikler ile aylık getiri grafiğinin incelenmesiyle, artık terimlerde otoregresif koşullu değişen varyanslılık (ARCH) bulunmalıdır [40]. Serilerde, ARCH etkisinin görülüp görülmediğini belirlemede ARCH-LM testi kullanılmaktadır.

Serilere ilișkin volatilitenin belirlenmesi için yapılan ARCH-LM testi Tablo 5'te yer almaktadır.

Tablo 5. ARCH-LM Testi

\begin{tabular}{ccccc}
\hline \multicolumn{5}{c}{ ARCH Testi } \\
\hline $\begin{array}{c}\text { Şirket } \\
\text { Adl }\end{array}$ & F & $\begin{array}{c}\text { Gözlemlerin } \\
\boldsymbol{R}^{2} \text { değeri }\end{array}$ & $\begin{array}{c}\text { Olasillk } \\
(\mathrm{F})\end{array}$ & $\begin{array}{c}\text { Olasllık } \\
\left(\chi^{2}\right)\end{array}$ \\
\hline AKENR & 237.498 & 81.919 & $<0,01$ & $<0,01$ \\
AKSUE & 373.384 & 93.462 & $<0,01$ & $<0,01$ \\
ZOREN & 191.203 & 75.699 & $<0,01$ & $<0,01$ \\
\hline
\end{tabular}

Test için yazılan istatistiksel hipotezler aşağıdaki gibi ifade edilmektedir [48]:

$H_{0}$ : ARCH etkisi yoktur.

$H_{1}$ :ARCH etkisi vardır.

şeklindedir.

Tablo 5'te yer alan olasılık değerleri 0.01 'den küçük olduğundan, H0: ARCH etkisi yoktur şeklinde ifade edilen hipotez reddedilir. Buradan da, ARCH-LM testi sonucuna göre, serilerde ARCH etkisi vardır. Volatilite tahmin modelleri Tablo 6'da verilmiştir.

Tablo 6. Volatilite Tahmin Modelleri

\begin{tabular}{lccccc}
\hline \multicolumn{5}{c}{ Volatilite Tahmin Modelleri } \\
\hline \multirow{2}{*}{ Şirket Adı } & \multirow{2}{*}{ Kriter } & $\begin{array}{c}\text { ARCH } \\
(5)\end{array}$ & $\begin{array}{c}\text { GARCH } \\
(1,1)\end{array}$ & $\begin{array}{c}\text { GJR-GARH } \\
(1,1)\end{array}$ & $\begin{array}{c}\text { EGARCH } \\
(1,1)\end{array}$ \\
\hline \multirow{2}{*}{ AKENR } & AIC & 5.429 & $\mathbf{2 . 3 5 2}$ & 2.355 & 2.561 \\
& SIC & 5.587 & $\mathbf{2 . 4 4 2}$ & 2.468 & 2.657 \\
\multirow{2}{*}{ AKSUE } & AIC & 4.068 & $\mathbf{4 . 0 5 5}$ & 4.066 & 4.073 \\
& SIC & 4.226 & $\mathbf{4 . 1 4 5}$ & 4.179 & 4.186 \\
\multirow{2}{*}{ ZOREN } & AIC & 1.878 & $\mathbf{1 . 8 4 3}$ & 1.850 & 1.918 \\
& SIC & 2.037 & $\mathbf{1 . 9 3 4}$ & 1.963 & 2.031 \\
\hline
\end{tabular}

Tablo 6 incelendiğinde; $\operatorname{GARCH}(1,1)$ modelinin, incelenen üç şirkete ait veriler için en uygun volatilite tahmin modeli olduğu söylemek mümkündür. AKERN için otokorelasyon grafiği Şekil 9'da verilmiştir.

\begin{tabular}{|c|c|c|c|c|c|c|}
\hline Autocorrelation & Partial Correlation & & AC & PAC & Q-Stat & Prob* \\
\hline 111 & 10 & 1 & -0.041 & -0.041 & 0.2155 & 0.642 \\
\hline 18. & 101 & 2 & -0.088 & -0.090 & 1.2146 & 0.545 \\
\hline 1 & 1 & 3 & -0.099 & -0.108 & 2.4924 & 0.477 \\
\hline 吗 & 由 & 4 & $=0.104$ & $=0.125$ & 3.9232 & 0.416 \\
\hline 11 & 101 & 5 & -0.032 & -0.068 & 4.0611 & 0.541 \\
\hline 111 & 111 & 6 & 0.016 & -0.026 & 4.0949 & 0.664 \\
\hline ( & $1 \boxminus$ & 7 & 0.332 & 0.308 & 18.880 & 0.009 \\
\hline 101 & 181 & 8 & -0.078 & $=0.065$ & 19.709 & 0.011 \\
\hline 11 & 11 & 9 & -0.040 & 0.007 & 19.925 & 0.018 \\
\hline 11 & 1 & 10 & -0.024 & 0.022 & 20.006 & 0.029 \\
\hline
\end{tabular}

Şekil 8. AKERN için Seri Korelasyon Grafiği

Uygun volatilite modeli bulunduktan sonra, serilerde otokorelasyonun olup olmadığının araştırılması gerekmektedir. Burada test edilen sıfır hipotezi "artık terimde otokorelasyon yoktur" şeklinde ifade edilmektedir. Şekil 9'a bakıldığında, otokorelasyon katsayılarının test edilmesinde yararlanılan olasılık değerleri genel olarak anlamlılık düzeyi olan 0.05 'ten büyüktür. Buna göre sıfır hipotezinin reddedilememektedir. $\mathrm{Bu}$ durumda, incelenen serilerde otokorelasyonun olmadı̆̆ını ifade etmek mümkündür.

Her bir şirket için ayrı ayrı yapılan volatiliteyi tahmin etmede $\operatorname{ARCH}(5), \operatorname{GARCH}(1,1), \operatorname{GJR}-\operatorname{GARCH}(1,1)$ ve EGARCH(1,1) modelleri kullanılmıştır. Yapılan analizde, Akaike ve Schwarz kriterlerine göre en düşük değeri olan modelin en uygun model olduğu belirlenmiştir. AKSUE için otokorelasyon grafiği Şekil 9'da verilmiștir.

\begin{tabular}{|c|c|c|c|c|c|c|}
\hline Autocorrelation & Partial Correlation & & $A C$ & PAC & Q-Stat & Prob* \\
\hline $1 p_{1}$ & י & 1 & 0.069 & 0.069 & 0.6124 & 0.434 \\
\hline id, & 10 1 & 2 & -0.086 & -0.091 & 1.5593 & 0.459 \\
\hline ין & 1 p & 3 & 0.121 & 0.136 & 3.4800 & 0.323 \\
\hline 1 & 11 & 4 & 0.020 & $=0.009$ & 3.5342 & 0.473 \\
\hline 1 & $1 \mathrm{~b}$ & 5 & 0.018 & 0.043 & 3.5788 & 0.612 \\
\hline ' & 111 & 6 & -0.003 & -0.025 & 3.5804 & 0.733 \\
\hline 101 & 101 & 7 & -0.061 & -0.056 & 4.0779 & 0.771 \\
\hline 1 1 & ' 1 & 8 & -0.118 & -0.122 & 5.9661 & 0.651 \\
\hline if 1 & 101 & 9 & -0.062 & -0.053 & 6.4904 & 0.690 \\
\hline 日. & 日. & 10 & 0.180 & $=0,191$ & 10.971 & 0.360 \\
\hline
\end{tabular}

Şekil 9. AKSUE için Seri Korelasyon Grafiği

Aksu Enerji'ye ait verilerin otokorelasyon içerip içermediği araştırılacak olursa; otokorelasyon katsayılarının test edilmesine ilişkin olasılık değerleri 0.05 'ten büyüktür ve bu durumda sıfır hipotezi reddedilememektedir. Buradan, serilerde otokorelasyonun olmadığı ifade edilebilmektedir. ZOREN için otokorelasyon grafiği Şekil 10'da verilmiştir.

\begin{tabular}{|c|c|c|c|c|c|c|}
\hline Autocorrelation & Partial Correlation & & $A C$ & PAC & Q-Stat & Prob* \\
\hline 101 & 111 & 1 & -0.044 & -0.044 & 0.2487 & 0.618 \\
\hline & & 2 & 0.047 & 0.045 & 0.5284 & 0.768 \\
\hline 181 & & 3 & -0.035 & -0.031 & 0.6847 & 0.877 \\
\hline 111 & 111 & 4 & 0.007 & 0.002 & 0.6905 & 0.952 \\
\hline 101 & 10 & 5 & -0.056 & -0.053 & 1.1047 & 0.954 \\
\hline 19 & 19 & 6 & $=0.054$ & -0.060 & 1.4948 & 0.960 \\
\hline 101 & 101 & 7 & -0.057 & -0.057 & 1.9292 & 0.964 \\
\hline 101 & 101 & 8 & -0.055 & -0.060 & 2.3416 & 0.969 \\
\hline 101 & 101 & 9 & -0.067 & -0.073 & 2.9629 & 0.966 \\
\hline 11 & 1,1 & 10 & 0.035 & 0.027 & 3.1366 & 0.978 \\
\hline
\end{tabular}

Şekil 10. ZOREN için Seri Korelasyon Grafiği

Zorlu Enerji'ye ait verilerin de otokorelasyon içerip içermediği araştırıldığında, otokorelasyon katsayılarının test edilmesinde dikkate alınan olasılık değerleri 0.05 'ten büyüktür. $\mathrm{Bu}$ durumda da otokorelasyonun olmadığını iddia eden hipotez reddedilememektedir.

Uygulamada yararlanılan Tarihi Simülasyon yöntemine göre; güven düzeyi $\% 95$ olarak belirlendiğinde, $01 / 10 / 2006$ - 31/12/2011 arası dönem için oluşturulan portföyün her bir hisse senedi için RMD değeri Çizelge Tablo 7'da verilmiştir.

Tablo 7 incelenecek olursa; hisse senetlerinden ilk olarak Ak Enerji için elde edilen sonuçlara bakıldığında; RMD değeri 1824. güne karşılık gelen değerdir. Başka bir şekilde ifade etmek gerekirse; güven düzeyi \%95 iken tarihi simülasyon yöntemine göre geçmişte yaşanan olayların tekrar etmesi durumunda Ak Enerji'nin hisse senedinde kaybedeceği tutar en fazla 0.053 TL dir. Aynı koşullar 
Tablo 7: Tarihi Simülasyon Yöntemi ile elde edilen RMD sonuçları

\begin{tabular}{|c|c|c|c|c|c|c|c|c|c|c|}
\hline \multicolumn{6}{|c|}{ Kayıр } & \multicolumn{5}{|c|}{ Kazanç } \\
\hline $\begin{array}{c}\text { Hisse } \\
\text { Senedi Adı }\end{array}$ & $\begin{array}{c}\text { Gözlem } \\
\text { Sayısı }\end{array}$ & $\begin{array}{l}\text { Güven } \\
\text { Aralığı }\end{array}$ & Gün & $\begin{array}{l}\text { RMD } \\
\text { (TL) }\end{array}$ & Tarih & $\begin{array}{c}\text { Gözlem } \\
\text { Sayısı }\end{array}$ & $\begin{array}{l}\text { Güven } \\
\text { Aralığı }\end{array}$ & Gün & $\begin{array}{l}\text { RMD } \\
\text { (TL) }\end{array}$ & Tarih \\
\hline AKENR & \multirow{3}{*}{1918} & \multirow{3}{*}{$\% 95$} & \multirow{3}{*}{1824} & 0.053 & $\begin{array}{c}14 / 01 / \\
2007\end{array}$ & \multirow{3}{*}{1918} & \multirow{3}{*}{$\% 5$} & \multirow{3}{*}{96} & 0.036 & $\begin{array}{c}14 / 11 / \\
2006 \\
\end{array}$ \\
\hline AKSUE & & & & 0.039 & $\begin{array}{c}18 / 09 / \\
2009\end{array}$ & & & & 0.010 & $\begin{array}{c}01 / 12 / \\
2010\end{array}$ \\
\hline ZOREN & & & & -0.032 & $\begin{array}{c}19 / 12 / \\
2011\end{array}$ & & & & 0.008 & $\begin{array}{c}16 / 05 / \\
2011\end{array}$ \\
\hline
\end{tabular}

tekrarlandığında \%5 güven düzeyinde Ak Enerji'nin kazanabileceği tutar 0.036 TL dir. Aksu Enerji'nin ise kaybedeceği tutar en fazla 0.039 TL iken; kazanacağ tutar 0.010 TL dir. Son olarak Zorlu Enerji'nin RMD değerlerine bakıldığında kaybedeceği tutar -0.032 TL iken; kazanabileceği tutar 0.008 TL dir.

\section{Tartışma ve Sonuç}

Yenilenemez (geleneksel) ve yenilenebilir enerji kaynakları olmak üzere iki tür enerji kaynağı vardır. Yenilenemez (Geleneksel) enerji kaynaklarının her geçen gün azalması nedeniyle ülkeleri yenilebilir enerji kaynaklarına yönelmektedir. Yenilenebilir enerji kaynaklarından enerji ede etmek üzere teşvikler sağlanmaktadır. Enerji ve enerji kaynakları günlük yaşantımızda oldukça önemli bir yer olduğundan, enerji sektörü önem kazanmıştır. Tüm bu gelişmelerin yaşanmasıyla, Türkiye'de de enerji sektöründe iyileştirmeler yapılması ve özellikle yenilebilir enerji kaynaklarından daha çok yararlanılması kaçınılmaz bir gerçektir.

Bu çalışmada, Türkiye'deki enerji sektöründe yer alan ve Menkul Kıymetler Borsası'nda işlem gören Ak Enerji Elektrik Üretim A.Ş. , Aksu Enerji ve Ticaret A.Ş. (BİST 100'de yer alan), ve Zorlu Enerji Elektrik Üretim A.Ş. (BIST 50'de yer alan) için 20082018/05 dönemi arasındaki aylık kapanış fiyatları incelenmiştir. İncelenen dönemde, Zorlu Enerji ve Ak Enerji verilerinde düşüşler görülürken, Aksu Enerji verilerinde artışların olduğu gözlenmiştir. Ak Enerji ve Zorlu Enerjiye ait kapanıș fiyatları verilerinde yaşanan düşüşlerin enerji sektöründeki gelişen teknolojinin gerisinde kaldıkları; Aksu Enerji'nin ise gelişime ayak uydurduğu şeklinde yorumlanabilmektedir.

$\mathrm{Bu}$ verilerin kullanılmasıyla, RMD hesaplamalarının performansının etkileneceğinden dolayı; her bir şirket için volatiliteyi tahmin etmede model önerisinde bulunmak amaçlanmıştır. Çalışmada dört farklı volatilite modeli kullanılmıştır. İncelenen şirketlerin verilerine ilişkin volatilite tahmin edilmesinde, riski modellemede, $\operatorname{GARCH}(1,1)$ modelinin en uygun model olduğu sonucuna ulaşılmıştır.

Ak Enerji için RMD değeri 1824. güne karşılık gelen değer olarak elde edilmiştir. Bunun anlamı \%95 güven düzeyinde $\mathrm{Ak}$ Enerji'nin hisse senedinde kaybedeceği tutar en fazla 0.053 TL demektir. Aynı koşullar tekrarlandığında $\% 5$ güven düzeyinde $\mathrm{Ak}$ Enerji'nin kazanabileceği tutar 0.036 TL dir. Aksu Enerji için ise kaybedeceği tutarın en fazla 0.039 TL ve kazanacağı tutarın da 0.010 TL olduğu belirlenmiștir. Zorlu Enerji'nin RMD değerleri incelendiğinde ise, kaybedeceği tutarın 0.032 TL iken; kazanabileceği tutar 0.008 TL olarak belirlenmiştir.

Çalışmadan elde edilen sonuçlar değerlendirildiğinde, şirketlerin bulundukları yerlerini korumak, geliştirmek ve ülke ekonomisinde daha fazla etkili olmak için teknolojiyi daha yakından takip etmeleri ve kullanmaları gerektiği ifade edilebilir. Ayrıca, çalışmada belirlenen uygun volatilite tahmin yöntemleri kullanılıp gelecekteki yaşanabilecek riskleri öngörüp, duruma göre önlem almaları gerektiği düşünülmektedir. Bu konuda bu iş sadece enerji şirketlerine düşmemektedir. Makro politika olarak karar vericilerin enerji sektörüne daha fazla önem vermeleri ve mevcut kaynaklardan daha fazla yararlanma konusunda teşvik edici kararlar vermeleri ve ortaya çıkacak riskin ölçülmesiyle, meydana gelebilecek zararın en az düzeyde gerçekleşmesi için çalışmaların yapılması gerektiği düşünülmektedir.

\section{Etik Beyanı/Declaration of Ethical Code}

$\mathrm{Bu}$ çalışmada, "Yükseköğretim Kurumları Bilimsel Araştırma ve Yayın Etiği Yönergesi" kapsamında uyulması gerekli tüm kurallara uyulduğunu, bahsi geçen yönergenin "Bilimsel Araştırma ve Yayın Etiğine Aykırı Eylemler" başlığı altında belirtilen eylemlerden hiçbiriningerçekleştirilmediğini taahhüt ederiz.

\section{Teşekkür}

Bu makale, Doç. Dr. Fatih Çemrek Danışmanlığında Tuğba Bitirgen tarafından Eskişehir Osmangazi Fen Bilimleri Enstitüsü İstatistik Anabilim Dalında hazırlanan ve Ağustos 2018 yılında kabul edilen “Riske Maruz Değer ve Borsa İstanbul'da İşlem Gören Bazı Hisse Senetleri Üzerine Bir Uygulama" başlıklı Yüksek Lisans Tezinden üretilmiştir.

\section{Kaynakça}

[1] İlhan Dalbudak, Z. 2014. Portföy riskinin ölçülmesine İstatistiksel bir yaklaşım: riske maruz değer analizi ve farklı portföyler üzerine uygulama. Eskişehir Osmangazi Üniversitesi Fen Bilimleri Enstitüsü, Yüksek Lisans Tezi, 116s, Eskişehir. 
F. Çemrek ve T. Bitirgen/Riske Maruz Değer ve Borsa İstanbul'da İşlem Gören Bazı Enerji Sektörü Hisse Senetleri Üzerine Bir Uygulama

[2] Akbalık, M., Kavcıoğlu, Ş. 2013. Energy Sector Outlook in Turkey. Dumlupınar Üniversitesi Sosyal Bilimler Dergisi, EYİ Özel Sayısı, 97-118.

[3] Balıbey, M., Türkyılmaz, S. 2014. Value-at-Risk Analysis in the Presence of Asymmetry and Long Memory: The Case of Turkish Stock Market. International Journal of Economics and Financial Issues 4(4), 836-848.

[4] Berkowitz, J., O’Brien, J. 2002. How accurate are Value at Risk Models at Commercial Banks? Journal of Finance, 57 (3), 1093-1111.

[5] Gürsakal, S., 2007. Hisse Senedi ve Döviz Piyasası Risklerinin Riske Maruz Değer Yöntemi İle Karșılaștırılması. Uludağ Üniversitesi İktisadi ve İdari Bilimler Fakültesi Dergisi, 26(2), 61-76.

[6] Aktaş, M., 2008. Türkiye Piyasalarında Parametrik Riske Maruz Değer Modelinin Taşıdığı Riskler. Afyon Kocatepe Üniversitesi İktisadi ve İdari Bilimler Dergisi, 10(1), 243-256.

[7] Uçkun, N., Kandemir S. 2008. Risk Ölçümünde Riske Maruz Değer Metodolojisi ve İMKB'de Bir Uygulama. Muhasebe ve Finans Dergisi, 38, 123131.

[8] Demireli,E., Taner, B. 2009. Risk Yönetiminde Riske Maruz Değer Yöntemleri ve Bir Uygulama. Süleyman Demirel Üniversitesi İktisadi ve İdari Bilimler Fakültesi Dergisi, 4(3), 127-148.

[9] Eser, Ö. 2010. Piyasa Riski Ölçümü Olarak Riske Maruz Değer ve Hisse Senedi Portföyleri İçin Bir Uygulama. Kadir Has Üniversitesi Sosyal Bilimler Enstitüsü, Yüksek Lisans Tezi, 96s, İstanbul.

[10] Korkmaz, T., Bostancı, A. 2011. RMD Hesaplamalarında Volatilite Tahminleme Modellerinin Karşılaștırılması ve Basel II Yaklașımına Göre Geriye Dönük Test Edilmesi: IMKB 100 Endeksi Uygulaması. Business and Economics Research Journal, 2(3), 1-17.

[11] Yllmaz, B. 2013. Energy markets of Turkey and application of variance-covariance method in value at risk method for Turkey electricity stocks. Master Thesis, İzmir University of Economics. The Graduate School of Social Sciences, Master Thesis, 166s, İzmir.

[12] Sahi, A. Pahuja.A., Dogra, B. 2014. Different Risk Adjusted Performance Measures for Equity Mutual Funds: A Comparative Study of VaR and Traditional Measures. Proceedings of International Conference on Management, Marketing and Banking, (ICMMB) 01-02 April, IISRO, Pataya-Thailand,95-105.

[13] Huang, X. 2014. Analyzing value at risk and expected shortfall methods: the use of parametric, non-parametric, and semi-parametric models.
University of Manitoba, Faculty of Graduate Studies, Master Thesis, 88s, Winnipeg, Manitoba.

[14] Avşarlıgi,l N., Demir, Y., Doğru, E. 2015. Riske Maruz Değer Ölçüm Yöntemleri Aracılığıyla BIST'te İșlem Gören Spor Kulüpleri Üzerine Bir Uygulama. Eskișehir Osmangazi Üniversitesi Sosyal Bilimler Dergisi, 16(1), 81-107.

[15] Abdrashev, N. 2015. Comparison of Islamic and Conventional Bank Stocks by Value-At-Risk Method. Russian Review, 2(3), 50-57.

[16] Handika, R., Triandaru, S. 2016. Is the Best GARCH $(p, q)$ VaR Estimate Also The Best in Reality? An Evidence from Australian Interconnected Power Markets. International Journal of Energy Economics and Policy, 6(4), 814821.

[17] Rankovic, V., Drenovak ,M., Urosevic ,B., Jelic, R., 2016. Mean Univariate-GARCH VaR Portfolio Optimization: Actual Portfolio Approach. Computers and Operations Research, 72, 83-92.

[18] Akbulut, E. 2012. Risk yönetiminde riske maruz değer modeli ve bir firmanın taşıdığı döviz kuru riskinin rmd modeli ile ölçümü. Galatasaray Üniversitesi Sosyal Bilimler Enstitüsü İșletme Anabilim Dalı Dönem Projesi, 78s, İstanbul.

[19] Attila, İ. 2010. Gayrimenkul Geliştirme Projelerinde Risk Yönetimi. Marmara Üniversitesi İ.İ.B.F. Dergisi, 29(2), 387-406.

[20] Holton, G.A. 2018. Value-at-Risk, https://www.value-at-risk.net/value-at-risk (Erişim Tarihi: 10.09.2020).

[21] Ceylan, O. 2014, Risk Nedir? Finansal Risk Çeşitleri Nelerdir? http://piyasarehberi.org/piyasa/132-risk-nedirfinansal-risk-cesitleri-nelerdir (Erișim Tarihi: 25.03.2016).

[22] Hola A., 2012. Mathematical models of value at risk. University of West Bohemia,. Faculty of Applied Sciences Department of Mathematics, Bachelor Thesis, 74s, Pilsen, Czech Republic.

[23] Rodoplu G., Ayan E., 2008. Basel-II uzlaşısında piyasa riski yönetimi ve Türkiye açısından faiz riskine ilişkin bir uygulama. Süleyman Demirel Üniversitesi İktisadi ve İdari Bilimler Fakültesi Dergisi, 13(2), 1-28.

[24] Chang, Chia L., Martın, J. A. J., Maasoumı, E., Mcaleer, M., Amaral, T. P. 2016. Choosing Expected Shortfall over VAR in Basel III Using Stochastic Dominance. International Review of Economics and Finance, 60, 95-113.

[25] Linsmeier, T., Pearson, N. 1996. Risk Measurement: An Introduction to Value at Risk. 
F. Çemrek ve T. Bitirgen/Riske Maruz Değer ve Borsa İstanbul'da İșlem Gören Bazı Enerji Sektörü Hisse Senetleri Üzerine Bir Uygulama

ACE Reports, 45s., University of Illinois at UrbanaChampaign.

[26] Boateng, F. 2015. Estimating value at risk using extreme value theory: Is the two dimensional in homogeneous poisson model better than the others. University of Oulu, Master's Thesis, 59s.

[27] Jorion, P. 2001. Value at Risk: The New Benchmark For Managing Financial Risk. McGrawHill, New York, 544s.

[28] Haugland, J. 2011. Value-at-risk: A coherent measure of risk? University of Stavanger. Faculty of Science and Technology, Master's Thesis, 47s, Stavanger, Norway.

[29] Çelik, N., Kaya, F. M, 2010. Uç Değerler Yöntemi İle Riske Maruz Değer'in Tahmini Ve İstanbul Menkul Kiymetler Borsası Üzerine Bir Uygulama, Bankacılık ve Sigortacılık Araştırmaları Dergisi, 1(1), 19-32.

[30] Mabitsela, L. 2015. Evaluation of the South African equity markets in a value-at-risk framework. University of Pretoria, Department of Finance, Master Thesis, 60s, Hatfield, South Africa.

[31] Beytaş, N. 2008. Risk yönetim aracı olarak riskteki değer (VaR) yöntemi ile portföy riskinin ölçümüne ilişkin bir uygulama. Dokuz Eylül Üniversitesi Sosyal Bilimler Enstitüsü, Yüksek Lisans Tezi, 149s, İzmir.

[32] Anonim, 2020. , Holding Period, https://www.investopedia.com/terms/h/holding period.asp (Erişim Tarihi:10.06.2020).

[33] Kayahan, C., Topal, Y. 2009. Tarihsel Riske Maruz Değer (RMD) Finansal Riskleri Açıklamada Yeterli Midir? Süleyman Demirel Üniversitesi İktisadi ve İdari Bilimler Fakültesi Dergisi, 14(1), 179-198.

[34] Uğur, A., Bingöl, N. 2017, BİST İmalat Sanayinde Riskin Ölçülmesi: Riske Maruz Değer Yöntemiyle Bir Uygulama. Ömer Halisdemir Üniversitesi İktisadi ve İdari Bilimler Fakültesi Dergisi, 10(4) , 271-284.

[35] Berggren, E., Folkelid, F. 2014. Which GARCH model is best for value-at-risk? Uppsala University, Bachelor Thesis, 27s. Uppsala, Sweeden.

[36] Izmaylov, B. 2014. Value-at-risk: Strengths, caveats and considerations for risk managers and regulators. Aarhus University. Master Thesis, Aarhus, 100s, Denmark.
[37] Kulalı, İ. (2016), Variance-Covariance (Delta Normal) Approach of VaR Models: An Example From Istanbul Stock Exchange. Research Journal of Finance and Accounting, 7(3), 65-69.

[38] İlhan Dalbudak, Z., Atan, M., Yılmaz, V., 2017. Comparison of Value at Risk Methods: Application of ISE 30. Journal of Business Economics and Finance, 1(3), 254-263.

[39] Gustafsson, M., Lundberg, C. 2009. An empirical evaluation of value at risk. University of Gothenburg, Master Thesis, 55s, Goteborg, Sweeden.

[40] Li, Y.,2008, Evaluation of var calculation methods in Chinese stock market. University of Vaasa, Faculty of Business Studies, Master's Thesis, 71s, Vaasa, Finland.

[41] Yıldırım, H., Çolakyan, A. 2014. Finansal Yatırım Araçlarında Riske Maruz Değer Uygulaması. Dokuz Eylül Üniversitesi İktisadi ve İdari Bilimler Fakültesi Dergisi, 29(1),1-24.

[42] Manganelli, S., Engle, R. 2001. Value at risk models in finance. European Central Bank, Working Paper Series, 75s.

[43] Skretting, Per K. 2013. Value at risk analysis on equity portfolios by means of random orthogonal matrix simulation. University of Stavanger. Faculty of Science and Technology, Master's Thesis, 49s, Stavanger, Norway.

[44] Corkalo, S. 2011.Comparison Of Value At Risk Approaches On A Stock Portfolio. Croatian Operational Research Review, University of Split, 2(1), 81-90.

[45] Yüksek, F., 2016. Riske Maruz Değer, http://slideplayer.biz.tr/slide/2797502/

(Erişim tarihi: 25.08.2020).

[46] Yıldırım, H., Çolakyan A. 2014. Finansal Yatırım Araçlarında Riske Maruz Değer Uygulaması. Dokuz Eylül Üniversitesi İktisadi ve İdari Bilimler Fakültesi Dergisi, 29(1), 1-24.

[47] Ladokhin, S. 2009, Volatility modeling in financial Markets. Vrije Universiteit Amsterdam, Master Thesis, 59s, Amsterdam, Netherland.

[48] Aktaş, C., Akkurt, H., 2006. ARCH Modelleri ve Türkiye'ye Ait Otomobil Üretimi Verilerinin Farklı Varyanslığının İncelenmesi. Dumlupınar Üniversitesi Sosyal Bilimler Enstitüsü Dergisi, 16(2), 86-106. 